\title{
Mais UM ANo de VIDA: os deSAFIos da CONDUÇÃo DE UM PERIÓDICO CIENTÍFICO
}

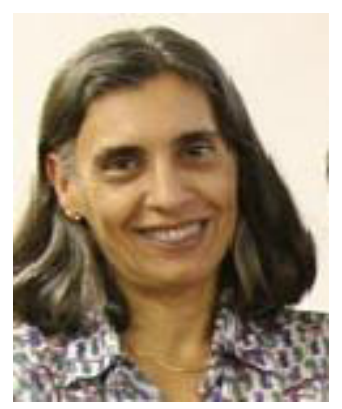

Cada fascículo de uma revista deve ser celebrado. Em especial quando ele inaugura um novo ano. Uma revista é um organismo vivo, complexo, precisa ser alimentado, cresce e se desenvolve, relaciona-se com uma comunidade, contribuindo com ela e recebendo dela contribuições. Esta revista tem, em sua missão, a veiculação de trabalhos na área de saúde mental, abarcando os diferentes matizes de sua abordagem, impondo dificuldades para os editores e assessores $a d$ hoc que se veem na condição de enviar os textos para análise para quem possa contribuir com avaliação construtiva e que, antes de qualquer coisa, tenha essa disponibilidade.

Por outro lado, é requerido dos autores que construam um bom relato de seu estudo. A SMAD disponibiliza orientações detalhadas, visando auxiliá-los nessa tarefa, mas é importante lembrar que no campo da saúde, onde se congregam diferentes áreas do conhecimento e, consequentemente, diferentes referenciais teórico-metodológicos, caminhamos entre a busca de regularidades, mas não podemos fechar os olhos para aquilo que é particular. No que tange à saúde mental, de forma mais contundente, emerge a noção de que se trabalha com objetos do universo psicossocial, cuja apreensão requer abertura a diferentes perspectivas. Assim, além de conduzir projetos de pesquisa bem delineados, cabe ao pesquisador criar relatos bem construídos que facilitarão o trabalho de análise, aumentando a chance de que sejam publicados.

Da agilidade do fluxo dos trabalhos recebidos por esse processo de avaliação depende a qualidade e a superposição entre a data cronológica e a data de publicação correspondente. Uma revista não pode ter defasagem ano cronológico e ano de publicação. Esse é um importante índice de maturidade que qualifica a revista para indexação em bases que alcançam maior número de leitores. Nossa revista vive, nesta etapa de sua vida, essa condição. Quando iniciei esse editorial chamando para a celebração é porque, a despeito das dificuldades, se alcança um produto que se pretende cada vez melhor.

No presente fascículo, conta-se com a colaboração de pesquisadores/autores que tratam dos seguintes temas: problemas de saúde mental (estresse, ansiedade e depressão) e uso de álcool entre funcionários públicos de uma universidade paulista de autoria de Gavin e colaboradores, pesquisadores da Escola de Enfermagem de Ribeirão Preto/USP; consumo de álcool e drogas entre profissionais de saúde, de autoria de David e Rocha; percepção de usuários de álcool de seu tratamento, realizado em Medellín, Colômbia por Prieto; disponibilização de informações sobre a doença e o tratamento a pacientes psiquiátricos, de autoria de Seicenti e Ventura; luto em idosas viúvas, de autoria de Costa e Labate, e religiosidade/espiritualidade como elemento protetor para o uso de drogas em adolescentes, de autoria de Felipe, Carvalho e Andrade.

A leitura desses trabalhos mostrará ampla gama de estratégias metodológicas e referenciais teóricos que expressam a complexidade dos temas tratados e o intercâmbio entre diferentes áreas do conhecimento.

Que ela possa subsidiar outros trabalhos e, assim, cumprir seu papel de fazer circular o conhecimento sobre questões que afetam a saúde mental das pessoas, nos diferentes contextos em que elas se encontram.

Boa leitura!

\section{Ana Maria Pimenta Carvalho}

Co-editora, SMAD - Revista Eletrônica Saúde Mental Álcool e Drogas. Professor Associado, Escola de Enfermagem de Ribeirão Preto, Universidade de São Paulo, Centro Colaborador da OPAS/OMS para o Desenvolvimento da Pesquisa em Enfermagem, Ribeirão Preto, SP, Brasil, e-mail: anacar@eerp.usp.br. 